\title{
Viscum album L. Extracts Protects HeLa Cells against Nuclear and Mitochondrial DNA Damage
}

\author{
Evren Önay-Uçar, ${ }^{1}$ Özlem Erol, ${ }^{2}$ Başak Kandemir, ${ }^{3}$ Elif Mertoğlu, ${ }^{4}$ \\ Ali Karagöz, ${ }^{1}$ and Nazlı Arda ${ }^{1}$ \\ ${ }^{1}$ Department of Molecular Biology and Genetics, Faculty of Science, Istanbul University, Vezneciler, 34118 Istanbul, Turkey \\ ${ }^{2}$ Department of Biology, Faculty of Sciences and Arts, Çanakkale Onsekiz Mart University, Terzioglu Campus, 17020 Çanakkale, Turkey \\ ${ }^{3}$ Department of Genetics and Bioengineering, Molecular Neurobiology Laboratory, Yeditepe University, 26 Agustos Campus Kayisdagi \\ Street, Kayisdagi, 81120 Istanbul, Turkey \\ ${ }^{4}$ Institute of Forensic Sciences, Istanbul University, Cerrahpaşa Campus, 34303 Istanbul, Turkey
}

Correspondence should be addressed to Özlem Erol, ozlemerolbio@gmail.com

Received 14 June 2012; Accepted 27 July 2012

Academic Editor: José Luis Ríos

Copyright (๑) 2012 Evren Önay-Uçar et al. This is an open access article distributed under the Creative Commons Attribution License, which permits unrestricted use, distribution, and reproduction in any medium, provided the original work is properly cited.

\begin{abstract}
Viscum album L. is a semiparasitic plant grown on trees and widely used for the treatment of many diseases in traditional and complementary therapy. It is well known that some activities of Viscum album extracts are varied depending on the host trees, such as antioxidant, apoptosis-inducing, anticancer activities of the plant. The aim of the present study is to examine the comparative effects of methanolic extracts of $V$. album grown on three different host trees (locust tree, lime tree, and hedge maple tree) on $\mathrm{H}_{2} \mathrm{O}_{2}$-induced DNA damage in HeLa cells. Oxidative damage in mitochondrial DNA and two nuclear regions was assessed by QPCR assay. The cells were pretreated with methanolic extracts $(10 \mu \mathrm{g} / \mathrm{mL})$ for $48 \mathrm{~h}$, followed by the treatment with $750 \mu \mathrm{M} \mathrm{H}_{2} \mathrm{O}_{2}$ for 1 hour. DNA damage was significantly induced by $\mathrm{H}_{2} \mathrm{O}_{2}$ while it was inhibited by V. album extracts. All extracts completely protected against nuclear DNA damage. While the extract from lime tree or white locust tree entirely inhibited mitochondrial DNA damage, that from hedge maple tree inhibited by only $50 \%$. These results suggest that methanolic extracts of $V$. album can prevent oxidative DNA damage, and the activity is dependent on the host tree.
\end{abstract}

\section{Introduction}

Reactive oxygen species (ROS) which originate from a range of cellular processes, external factors, and/or various diseases can damage cellular components [1]. The enzymatic and nonenzymatic antioxidant defense systems are natural protectors against oxidative stress caused by ROS. However, these mechanisms cannot completely protect DNA against damage [2]. Although oxidative DNA damage can be repaired, unrepaired damage can accumulate in the cell. The most dramatic results of this accumulation are mutations and cell death [3]. Hence, oxidative DNA damage is an important factor for the aging process and age-related diseases, such as cancer $[1,4,5]$.
Viscum album L. (mistletoe) is a semiparasitic perennial plant that grows on different host trees [6]. Different Viscum album extracts have been used in traditional medicine for the treatment of various diseases such as stroke, atherosclerosis, hypertension, and diabetes [7]. This plant has many biological activities such as anticancer, antiviral, antioxidant, apoptosis-inducing and immunomodulatory properties [815]. Although methanolic extract of Viscum album leaves is able to reduce the malondialdehyde (MDA) and reduce glutathione (GSH) levels on kidney and heart of streptozotocininduced diabetic rats and has strong antioxidant activity [11-13], the effect on oxidative DNA damage has not been examined in HeLa cells. The main purpose of the present study is to investigate whether the methanolic extract of 
Viscum album protects nDNA and mtDNA against $\mathrm{H}_{2} \mathrm{O}_{2}$ induced oxidative stress in HeLa cells.

\section{Materials and Methods}

2.1. Plant Materials. Viscum album L. plants grown on three different host trees (lime tree (Tilia argentea Desf. Ex DC, Tv), hedge maple tree (Acer campestre L. ssp. campestre, $\mathrm{Av}$ ), and locust tree (Robinia pseudoacacia L., Rv)) were harvested from the Northern part of Istanbul in September 2006. The voucher specimen was identified and deposited in the Herbarium of Biology Department, Istanbul University, Istanbul, Turkey (Tv, ISTF 37486; Av, ISTF 37487; Rv, ISTF 37488). Fresh leaves of each sampling were picked and washed by tap water, followed by distilled water. After drying they were cut into small pieces, weighed, and used immediately or stored separately at $-20^{\circ} \mathrm{C}$ until use.

2.2. Preparation of Extracts. The extracts were prepared as described earlier [12]. Fresh leaves (20 g) were macerated in methanol $(160 \mathrm{~mL})$ in an incubatory shaker $(150 \mathrm{rev} / \mathrm{min}$, $25^{\circ} \mathrm{C}$ ) for 24 hours. After removing the plant residues by filtration, each filtrate was evaporated to dryness under vacuum, and the dried material was weighed. Crude extracts were dissolved in DMSO at a concentration of $40 \mathrm{mg} / \mathrm{mL}$ and stored at $-20^{\circ} \mathrm{C}$ until use. They were designated according to the trees where the plants were collected as Tv (Tilia viscum), Av (Acer viscum), and Rv (Robinia viscum).

2.3. Cell Culture. Human HeLa cervical carcinoma cells were cultured in Eagle's Minimum Essential Medium (EMEM) supplemented with $10 \%(\mathrm{v} / \mathrm{v})$ heat-inactivated fetal bovine serum and antibiotic-antimycotic mixture (penicillin $(100 \mathrm{U} / \mathrm{mL})$, streptomycin $(100 \mu \mathrm{g} / \mathrm{mL})$, amphotericin $\mathrm{B}(0.25 \mu \mathrm{g} / \mathrm{mL}))$. Cells were seeded at a concentration of $10^{5}$ cells $/ \mathrm{mL}$ and maintained at $37^{\circ} \mathrm{C}$ in an atmosphere with $5 \% \mathrm{CO}_{2}$. $V$. album extract was added to the growth medium, after dissolving in DMSO at a final concentration not exceeding $0.5 \%(\mathrm{v} / \mathrm{v})$, since DMSO is able to inhibit cell growth above this concentration (data not shown).

2.4. Cytotoxicity Test. The cytotoxic activity of the extracts was tested on HeLa cells by using the 3-(4,5-dimethylthiazol2-yl)-2,5-diphenyltetrazolium bromide (MTT) assay based on the reduction of MTT to a colored formazan product by mitochondrial dehydrogenase, which is active only in living cells [16]. The stock solutions of the extracts were diluted with EMEM. Cells $\left(10^{5}\right.$ cells $\left./ \mathrm{mL}\right)$ were seeded into each well of a 96-well plate, containing $200 \mu \mathrm{L}$ EMEM. After reaching confluence ( $24 \mathrm{~h}$ later), the cells were treated with increasing concentrations $(1-500 \mu \mathrm{g} / \mathrm{mL})$ of $V$. album methanol extract diluted with EMEM for $48 \mathrm{~h}$. To determine cytotoxic activity of $\mathrm{H}_{2} \mathrm{O}_{2}$ the cells were treated with different concentrations $(0.05-5 \mathrm{mM})$ of $\mathrm{H}_{2} \mathrm{O}_{2}$ diluted with Hank's balanced salt solution (HBBS) for $1 \mathrm{~h}$ at the end of $72 \mathrm{~h}$. In the next step, upper layers were discarded. After washing the adherent cells with phosphate buffer saline (PBS) to minimize the interference of upper layer residue, $10 \mu \mathrm{L}$ of
MTT stock solution ( $5 \mathrm{mg} / \mathrm{mL}$ ) was added to each well, and the plates were further incubated for 4 hours at $37^{\circ} \mathrm{C}$. After formation of water insoluble purple formazan crystals, they were dissolved in $200 \mu \mathrm{L}$ of DMSO, and the resulting optical density was measured by a microplate reader ( $\mu$ Quant, BioTek Instruments Inc., Winooski, VT, USA) at $570 \mathrm{~nm}$ and $690 \mathrm{~nm}$ (reference) wavelengths. The cell viability was calculated as percentage of viable cells in experimental group versus untreated control group using the following formula:

$$
\text { cell viability }(\%)=\left(\frac{\mathrm{OD}_{\exp }}{\mathrm{OD}_{\text {control }}}\right) \times 100 \text {. }
$$

The $\mathrm{EC}_{50}$ doses on HeLa cells were calculated from a graph of cell viability versus methanolic extract of $V$. album and nontoxic dose of the plant extract $(10 \mu \mathrm{g} / \mathrm{mL})$ was used for further experiments.

2.4.1. Treatment of Extracts. HeLa cells $\left(10^{5}\right.$ cells $\left./ \mathrm{mL}\right)$ were incubated with noncytotoxic doses of $V$. album extracts $(10 \mu \mathrm{g} / \mathrm{mL})$ for experimental groups or solely with EMEM for the untreated control in the last 48 hours of the total incubation time of 72 hours.

2.4.2. Induction of Oxidative Stress. Oxidative stress was induced by $\mathrm{H}_{2} \mathrm{O}_{2}$ at $50 \mu \mathrm{M}$ and $100 \mu \mathrm{M}$, and the depletion of $\mathrm{H}_{2} \mathrm{O}_{2}$ in the cell culture medium was measured. ROS generation was enhanced by treatment of the cells with $200 \mu \mathrm{M} \mathrm{H} \mathrm{H}_{2} \mathrm{O}_{2}$. Harsh stress conditions to induce DNA damage were created by $750 \mu \mathrm{M} \mathrm{H}_{2} \mathrm{O}_{2}$. After treatment with the extracts, the cells were washed with PBS and then treated with $\mathrm{H}_{2} \mathrm{O}_{2}$ for $1 \mathrm{~h}$. Hank's balanced salt solution (HBSS) was used to dilute the $\mathrm{H}_{2} \mathrm{O}_{2}$ and as a blank in the assays. $\mathrm{H}_{2} \mathrm{O}_{2}$ concentration was checked by absorbance at $240 \mathrm{~nm}$, as described by Aebi [17].

Depletion of $\mathrm{H}_{2} \mathrm{O}_{2}$ in culture media was measured at 10 , 30 and $60 \mathrm{~min}$ as indicated in Figure 2 by the colorimetric method of Pick and Keisari [18]. In this assay $\mathrm{H}_{2} \mathrm{O}_{2}$ is reduced while phenol red is oxidized by the action of HRP. The final purple product exhibits maximum absorption at $612 \mathrm{~nm}$. Briefly, the cells $\left(10^{5}\right.$ cells $\left./ \mathrm{mL}\right)$ were seeded into each well, containing $200 \mu \mathrm{L}$ EMEM in a 96-well plate. Cell-free (negative) controls were run in parallel with the experimental groups. The cell culture medium $(100 \mu \mathrm{L})$ containing HBSS plus $50 \mu \mathrm{M}$ and $100 \mu \mathrm{M} \mathrm{H}_{2} \mathrm{O}_{2}$ was thoroughly mixed with $200 \mu \mathrm{L}$ phenol red/horseradish peroxidase solution. The mixture was incubated at $37^{\circ} \mathrm{C}$ for $5 \mathrm{~min}$, and the reaction was terminated by adding $2 \mu \mathrm{L}$ of $1 \mathrm{~N} \mathrm{NaOH}$. $\mathrm{H}_{2} \mathrm{O}_{2}$ concentrations were calculated using a standard curve of $\mathrm{H}_{2} \mathrm{O}_{2}$ versus absorbance $(610 \mathrm{~nm})$. The standard curve showed a linear relationship between absorbance at $610 \mathrm{~nm}$ and $\mathrm{H}_{2} \mathrm{O}_{2}$ concentration in the $12.5-100 \mu \mathrm{M}$ range.

2.4.3. Intracellular ROS Level. Intracellular ROS level was estimated by using a fluorescent probe, $2^{\prime}, 7^{\prime}$ dichlorofluorescein diacetate (DCFH-DA) [19]. After incubation and exposure to oxidative stress, the culture medium was immediately removed, and the cells were washed with PBS followed by incubation for $15 \min$ in $10 \mu \mathrm{M}$ 
DCFH-DA $(100 \mu \mathrm{L})$ at $37^{\circ} \mathrm{C}$ in an atmosphere with $5 \% \mathrm{CO}_{2}$. The fluorescence of hydrolyzed 2,7-dichlorofluorescein (DCF) was measured at $10 \mathrm{~min}$ intervals for $1 \mathrm{~h}$ in a microplate fluorometer with $485 \mathrm{~nm}$ excitation $/ 530 \mathrm{~nm}$ emission wavelengths (FLx800, BioTek Instruments Inc., Winooski, VT, USA). The relative percentage of ROS production was calculated according to the following equation:

$$
\operatorname{ROS}(\%)=\left(\frac{F_{1}}{F_{0}}\right) \times 100 \%,
$$

where $\mathrm{F}_{0}$ is fluorescence intensity of untreated control group and $F_{1}$ is fluorescence intensity of experimental group.

2.5. DNA Isolation. High molecular weight total cellular DNA was isolated with the GenElute Mammalian Genomic DNA Isolation kit (Sigma, St. Louis, MO), according to the manufacturer's protocol. The concentration of total cellular DNA was determined by using the Quant-iT dsDNA High Sensitivity Assay Kit in a Qubit fluorometer (Invitrogen, Paisley, UK).

2.6. Quantitative Polymerase Chain Reaction (QPCR). QPCR was carried out according to the method of Erol et al. [20]. Three different genomic regions were analyzed for oxidative damages. Oligonucleotide primers specific for a $2082 \mathrm{bp}$ fragment of the nuclear APEX1 gene (transcribed,GenBank ID: X66133) [21], a 2334 bp fragment of the nuclear $\beta$-globin gene cluster (nontranscribed, GenBank ID: NG_000007), and a $2232 \mathrm{bp}$ fragment of the mtDNA (GenBank ID: AF347015) were used in the PCR reaction [20]. All PCR reactions were performed in Techne TC-3000 Thermocycler (Techne Inc., USA). The total volume of the reaction mixture was $50 \mu \mathrm{L}$, containing $100 \mathrm{ng}$ of DNA, $1 \mathrm{x}$ buffer (Fermentas), $0.2 \mathrm{mM}$ dNTPs, $1-2.5 \mathrm{mM} \mathrm{MgCl}_{2}, 0.3 \mu \mathrm{M}$ primers, and 2.5 unit of recombinant Taq DNA polymerase (Fermentas). A quantitative control using half of the concentration of control template DNA was included in each set of PCR reaction. The small fragments, $161 \mathrm{bp}$ for mitochondrial DNA and $181 \mathrm{bp}$ for nuclear region, were also amplified as internal controls to normalize the results obtained with the large fragments and to monitor mitochondrial copy number. An aliquot of each PCR product was checked by electrophoresis on a $1-2 \%(\mathrm{w} / \mathrm{v})$ vertical agarose gel at $70 \mathrm{~V}$ for $45 \mathrm{~min}$ in 1xTAE buffer (Tris-acetate-EDTA, $\mathrm{pH}$ 8.0). The amount of QPCR products was quantified using QuantiT dsDNA High Sensitivity Assay Kit. The average lesion frequency per each fragment was calculated using the Poisson equation [22].

2.7. Statistical Analysis. Data were expressed as mean \pm SEM of three independent experiments done in triplicates. All analyses were carried out using GraphPad Prism, version 5.00 for Windows, GraphPad software Inc., San Diego, CA, http://www.graphpad.com/. Statistical analyses were performed using one-way ANOVA followed by Dunnett's test. Differences between two groups relation to the depletion kinetics of $\mathrm{H}_{2} \mathrm{O}_{2}$ were evaluated by using the two-tailed
TABLE 1: Effect of pretreatment with Viscum album from different hosts on intracellular ROS generation.

\begin{tabular}{|c|c|c|}
\hline & \multicolumn{2}{|c|}{ Relative amount of intracellular ROS (\%) } \\
\hline & $\begin{array}{l}\text { No stress induction } \\
\quad\left(0 \mu \mathrm{M} \mathrm{H}_{2} \mathrm{O}_{2}\right)\end{array}$ & $\begin{array}{l}\text { Stress induction } \\
\left(200 \mu \mathrm{M} \mathrm{H}_{2} \mathrm{O}_{2}\right)\end{array}$ \\
\hline Untreated control & $100.00 \pm 0.41$ & $119.20 \pm 1.72^{* *}$ \\
\hline $\mathrm{GA}(28 \mu \mathrm{g} / \mathrm{mL})$ & $96.70 \pm 3.33$ & $102.20 \pm 2.46^{\bullet}$ \\
\hline $\operatorname{Tv}(10 \mu \mathrm{g} / \mathrm{mL})$ & $97.36 \pm 2.40$ & $108.63 \pm 1.64^{\circ}$ \\
\hline $\mathrm{Av}(10 \mu \mathrm{g} / \mathrm{mL})$ & $99.49 \pm 2.65$ & $101.10 \pm 2.26^{\bullet}$ \\
\hline $\operatorname{Rv}(10 \mu \mathrm{g} / \mathrm{mL})$ & $102.70 \pm 1.95$ & $108.61 \pm 2.45^{\bullet}$ \\
\hline
\end{tabular}

unpaired $t$-test. The probability values of $P<0.05$ were considered as significant.

\section{Results}

All extracts and $\mathrm{H}_{2} \mathrm{O}_{2}$ decreased the viability of HeLa cells in a dose-dependent manner (Figure 1). As illustrated in Figure 1, the half maximal inhibitory concentration $\left(\mathrm{IC}_{50}\right)$ of $\mathrm{Tv}, \mathrm{Av}, \mathrm{Rv}$, and $\mathrm{H}_{2} \mathrm{O}_{2}$ is $93 \mu \mathrm{g} / \mathrm{mL}, 165 \mu \mathrm{g} / \mathrm{mL}, 85 \mu \mathrm{g} / \mathrm{mL}$, and $810 \mu \mathrm{M}$, respectively. The noncytotoxic doses of all extracts $(10 \mu \mathrm{g} / \mathrm{mL})$ were used for further experiments in order to avoid cell death as a result of cytotoxicity. Oxidative stress was provoked by $50 \mu \mathrm{M}$ and $100 \mu \mathrm{M} \mathrm{H}_{2} \mathrm{O}_{2}$, and its depletion within $60 \mathrm{~min}$ was checked by monitoring the remaining $\mathrm{H}_{2} \mathrm{O}_{2}$ in the culture media. There were no significant differences between the depletion kinetics of both $50 \mu \mathrm{M}$ and $100 \mu \mathrm{M} \mathrm{H}_{2} \mathrm{O}_{2}$ of cells treated with extracts (Figure 2). Almost $80 \%$ of $\mathrm{H}_{2} \mathrm{O}_{2}$ in culture media were depleted by HeLa cells within 1 hour, while $\mathrm{H}_{2} \mathrm{O}_{2}$ level in cellfree culture medium remained stable. These results indicated that $\mathrm{H}_{2} \mathrm{O}_{2}$ did not interact with the components of medium, and depletion of $\mathrm{H}_{2} \mathrm{O}_{2}$ occurred via cellular metabolism [23].

The incubation of the HeLa cells with $200 \mu \mathrm{M} \mathrm{H}_{2} \mathrm{O}_{2}$ increased the level of ROS. Intracellular ROS production was increased by $19.2 \%$ in $\mathrm{H}_{2} \mathrm{O}_{2}$-treated cells compared with untreated control cells (Table 1). V. album methanolic extracts have no effect on the steady-state level of intracellular ROS. Av had the highest ROS inhibiting activity compared to $200 \mu \mathrm{M} \mathrm{H}_{2} \mathrm{O}_{2}$-treated cells. Also, other two extracts ( $\mathrm{Tv}$ and $\mathrm{Rv}$ ) were found to have significant inhibitory effects on ROS generation following the oxidative stress induction (Table 1) by using gallic acid (GA) as reference substance.

The gene-specific QPCR assay was performed on nuclear regions (APEX1 and $\beta$-globin) and mitochondrial DNA for the detection of oxidative damage caused by $\mathrm{H}_{2} \mathrm{O}_{2}$. The assay is based on the fact that many DNA lesions can block the Taq polymerase, and as a result, the product amplification is decreased [24]. When the different $\mathrm{H}_{2} \mathrm{O}_{2}$ concentrations ( 300 and $750 \mu \mathrm{M}$ ) were applied to determine lesion frequencies in HeLa cells, it was found that in APEX1 and mtDNA regions were similarly induced by $300 \mu \mathrm{M}$ $\mathrm{H}_{2} \mathrm{O}_{2}$, while in $\beta$-globin region no significant induction was 


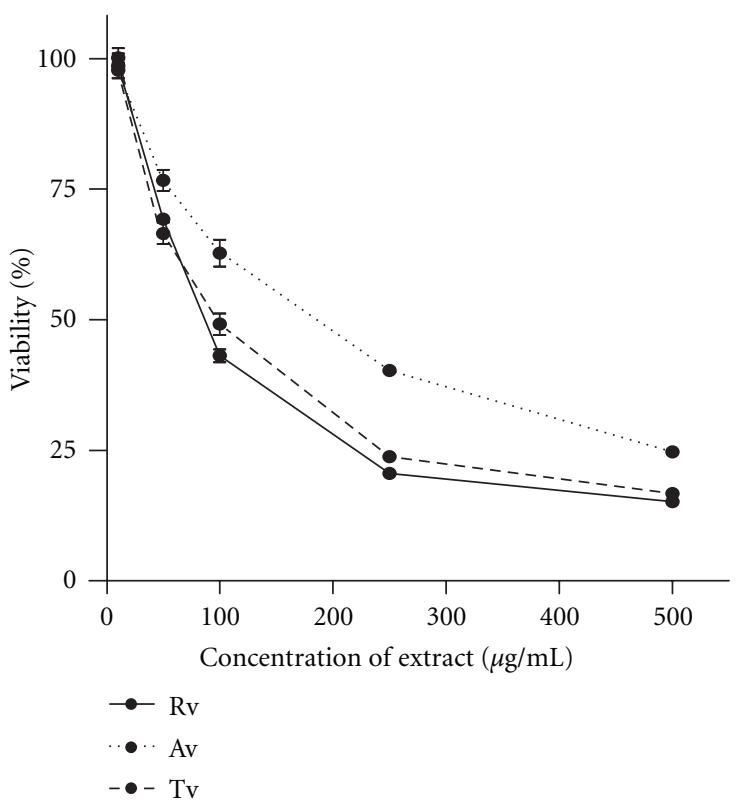

(a)

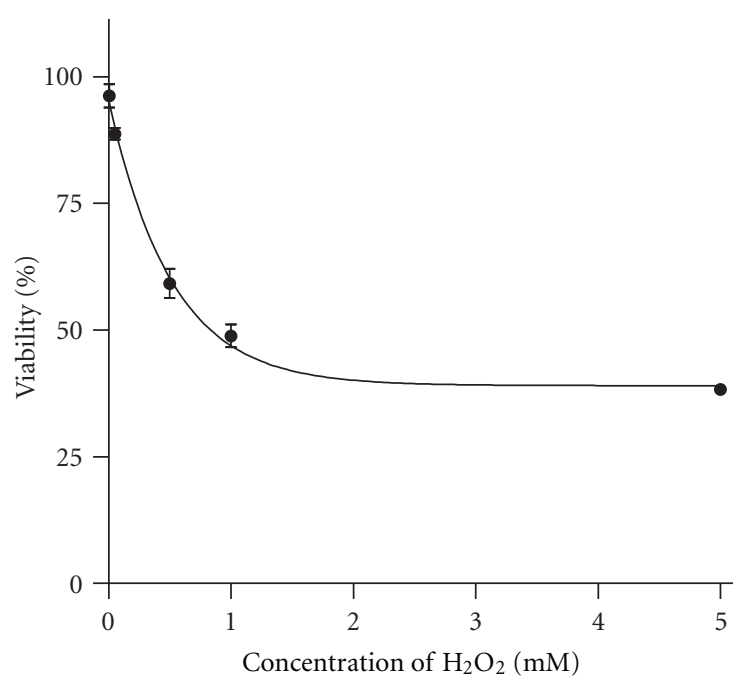

(b)

FIgURE 1: (a) Effect of methanolic extracts of Viscum album from different hosts on viability of HeLa cells, (b) cytotoxic effect of $\mathrm{H}_{2} \mathrm{O}_{2}$.

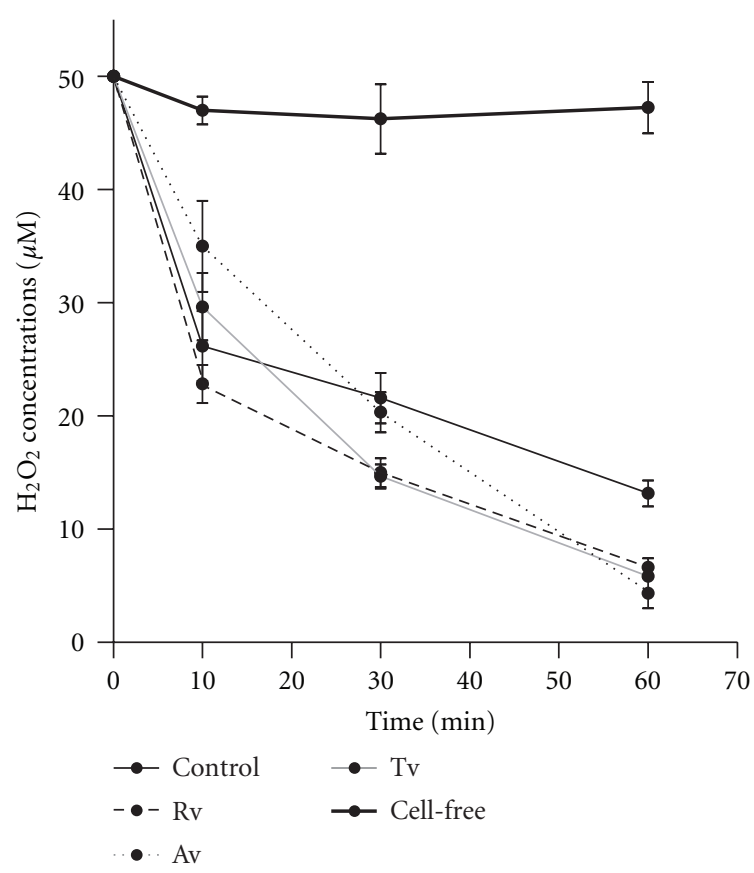

(a)

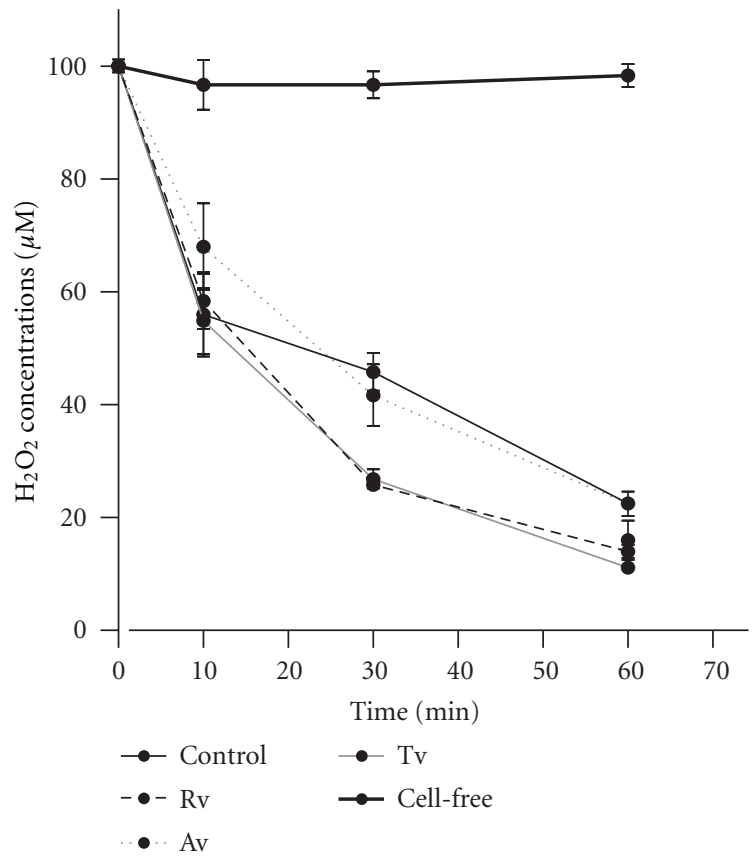

(b)

FIGURE 2: Effect of pretreatment with Viscum album extracts on depletion kinetics of (a) $50 \mu \mathrm{M}$ and (b) $100 \mu \mathrm{M} \mathrm{H} \mathrm{H}_{2} \mathrm{O}_{2}$ in culture media.

seen relative to control (unpublished data). Therefore, to determine the protective effect of the plant extract on cells, only $750 \mu \mathrm{M} \mathrm{H}_{2} \mathrm{O}_{2}$ has been applied. In this study, lesion numbers per $10 \mathrm{~kb}$ on both nuclear and mitochondrial DNA in HeLa cells incubated with or without Viscum extracts were very low under nonstressed conditions (Figure 3 ). A negative value obtained for $\mathrm{Tv}$ in the $\beta$-globin region indicated that lesion frequency was much lower than in the others $(P<0.05)$. However considerable damage in all regions was detected, after the control cells were treated by $750 \mu \mathrm{M}$ $\mathrm{H}_{2} \mathrm{O}_{2}$. Lesion frequency of mtDNA was higher 2 times than nDNA. As expected, mtDNA was the most sensitive 


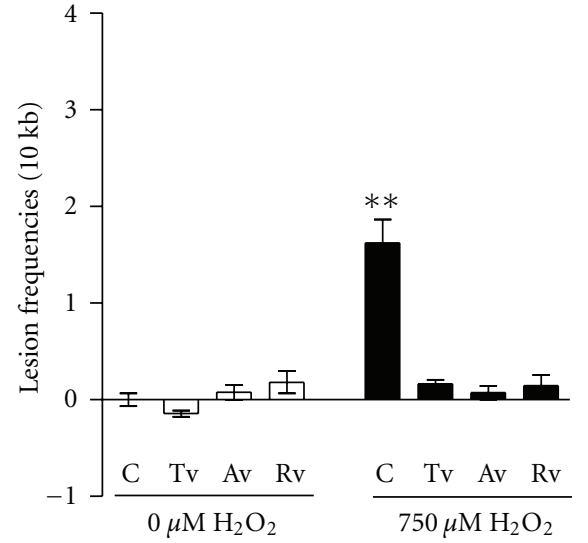

(a)

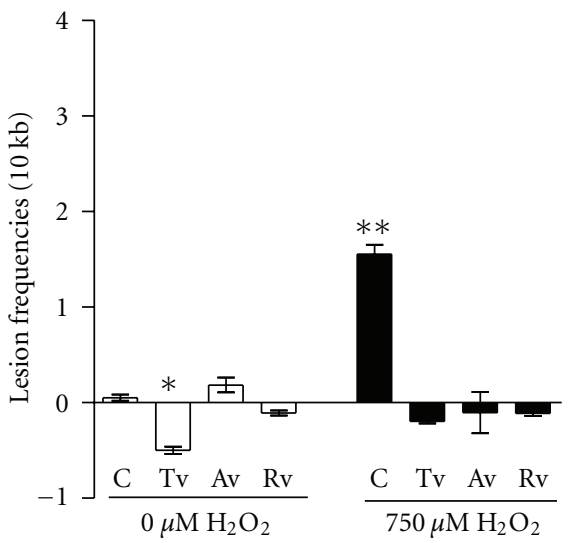

(b)

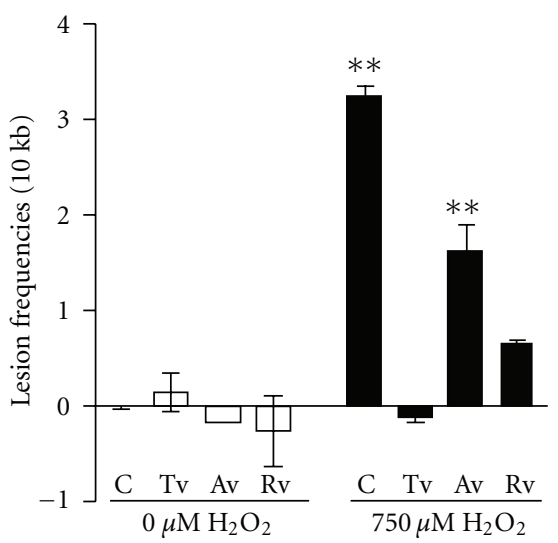

(c)

FIgURE 3: Effect of Viscum album extracts and/or $\mathrm{H}_{2} \mathrm{O}_{2}$ on (a) APEX1 gene; (b) $\beta$-globin region; (c) mtDNA in HeLa cells. C: Untreated control cells; $\mathrm{Tv}, \mathrm{Av}$, and Rv: Cells treated with $10 \mu \mathrm{g} / \mathrm{ml}$ of the corresponding extract for $48 \mathrm{~h}$. ${ }^{*} P<0.01$; mean value were significantly different from the untreated control.

to oxidative stress induced by $750 \mu \mathrm{M} \mathrm{H}_{2} \mathrm{O}_{2}$. It contained 3.2 lesions per $10 \mathrm{~kb}$ fragment, while transcribed (APEX1) and nontranscribed ( $\beta$-globin) nDNAs were less damaged (1.6 and 1.7 lesions per $10 \mathrm{~kb}$, resp.). In the experimental groups the methanolic extracts of Viscum album grown on different host trees exhibited different degrees of protective effect against oxidative DNA damage. Pretreatment with Rv and $\mathrm{Tv}$ extracts completely prevented the damage on both nuclear and mitochondrial DNA under stress conditions. However Av showed only $50 \%$ inhibition against mtDNA damage, while it was entirely effective against nDNA damage.

\section{Discussion}

Oxidative stress is an imbalance between formation of ROS and antioxidant defense, resulting in potential cellular damage [3]. Aging and several diseases such as cancers, diabetes, and degenerative disorders have been linked to oxidative stress caused by ROS $[1,25]$. In living cells ROS are the primary source of oxidative DNA damage under both physiological and increased oxidative stress conditions [25]. Eukaryotic cells protect themselves by antioxidant defence mechanisms such as enzymes, radical scavengers, hydrogen donors, electron donors, peroxide decomposers, singlet oxygen quenchers, enzyme inhibitors, synergists, and metal-chelating agents [26]. Antioxidants may also repair oxidative damage or enhance antioxidant defense either by induction of phase II enzymes or by stimulating mitochondrial biogenesis [27]. Hence, DNA, proteins, and lipid constituents of the cells are protected by antioxidants against oxidative damage. Plants contain various antioxidant constituents that act in different ways and are used in traditional medicine. Depending on the bioactivity, plant extracts as well as many compounds isolated from them are extensively used in pharmaceutical industry as an ingredient drugs or cosmetics; some of these are able to protect against molecular damage [28]. For example, various phenolics compounds and antioxidants reduce oxidative DNA damage in different cell types $[20,29,30]$.

The purpose of this study was to evaluate the protective effect of Viscum album methanolic extracts against nuclear and mitochondrial DNA damage in HeLa cells. In vitro antioxidant activity of this extract has been reported earlier $[12,13]$. In our previous study composition and activity of Viscum album methanolic extract are found to be dependent on the host tree as well as time of harvesting [12]. In this present study we first showed that Viscum album methanolic extracts are able to inhibit ROS formation induced by $\mathrm{H}_{2} \mathrm{O}_{2}$ in HeLa cells. Similar results were obtained in an animal study that reported protective effect of Viscum album against oxidative stress on kidney and heart of diabetic rats [11]. Hence, it is suggested that $V$. album may protect living cells by inhibition of ROS formation. Surprisingly, the experimental dose of $V$. album $(10 \mu \mathrm{g} / \mathrm{mL})$ used in the assay did not alter the level of basal damage of both nDNA and mtDNA when there was no induction of stress (Figure 3). This result may show that undetectable damage has occurred under physiological conditions. We also found that the mitochondrial genome is significantly $(P<0.001)$ more sensitive to $\mathrm{H}_{2} \mathrm{O}_{2}$-induced oxidative stress than both nuclear loci (Figure 3). Previous studies demonstrated that mtDNA is more susceptible to oxidative agents than nDNA $[23,31]$. The susceptibility of mtDNA to oxidative damage is due to chain-propagation reactions or electron leakage from the respiratory chain [32]. mtDNA does not have introns with a high transcription rate, providing a high probability of oxidative modification of the expressed region [33]. Also the presence of localized metal ions in mitochondria may function as catalysts for the generation of ROS and the stimulation of secondary ROS reactions due to damage to the ETC and/or through lipid peroxidation [23].

Furthermore, we demonstrate that Viscum album methanolic extracts are able to prevent DNA damage induced by $\mathrm{H}_{2} \mathrm{O}_{2}$. It is predicted that several thousand DNA lesions per cell occur each day in humans by different stress factors 
[34]. If the cells do not have effective DNA repair and/or antioxidant defense mechanisms, this damage accumulates in DNA (in especially mtDNA), and this may result in agerelated disorders. DNA damage in tumor suppressor genes and oncogenes may also be a likely cause of cancer [3-5]. Therefore it is especially significant that Viscum album can protect mtDNA, which has an important role in the aging and APEX1 gene (actively transcribed for a DNA repair enzyme) against this accumulation via inhibition of oxidative DNA damage. Nevertheless, no significant correlation between prevention of DNA damage and the inhibition of ROS was obtained, suggesting that the antioxidant potential of Viscum album extract is generated by a complex synergy and different mechanisms of active molecules, not only by ROS inhibition.

Antioxidant activity of plants is associated with their bioactive compounds, mainly antioxidant phenolics, because of their ability to scavenge free radicals. In $V$. album methanolic extracts, the total quercetin content was measured as $4.92 \mu \mathrm{g} / \mathrm{g}$ crude extract of $\mathrm{Tv}, 3.92 \mu \mathrm{g} / \mathrm{g}$ crude extract of $\mathrm{Av}, 7.97 \mu \mathrm{g} / \mathrm{g}$ crude extract of $\mathrm{Rv}$, respectively (unpublished data). Thus, the high quercetin content in $V$. album extract may be responsible for the protection of DNA damage in HeLa cells.

In conclusion, taken together these results suggest that methanolic extract of Viscum album can protect against DNA damage via direct inhibition of ROS formation and/or indirectly by other mechanisms, through induction of oxidative damage repair and phase II enzymes. Therefore, dietary intake of Viscum album extract may lower the risk of oxidative stress-mediated diseases such as some cancers, diabetic complications, degenerative and gastrointestinal diseases, or atherosclerosis via reduction of oxidative DNA damage and intracellular levels of ROS. Further studies are needed in order to define the possible beneficial outcomes of its dietary use and to identify mechanisms of action.

\section{Abbreviations}

Av: $\quad$ Viscum album grown on Acer campestre

GA: Gallic acid

GAE: Gallic acid equivalent

HBSS: Hank's balanced salt solution

mtDNA: Mitochondrial DNA

nDNA: Nuclear DNA

QPCR: Quantitative PCR

Rv: $\quad$ Viscum album grown on Robinia pseudoacacia

Tv: Viscum album grown on Tilia argentea.

\section{Conflict of Interests}

The authors declare that they have no conflict of interest.

\section{Acknowledgment}

This study was supported by the Research Fund of Istanbul University (Project no. 1462).

\section{References}

[1] V. A. Bohr, "Repair of oxidative DNA damage in nuclear and mitochondrial DNA, and some changes with aging in mammalian cells," Free Radical Biology and Medicine, vol. 32, no. 9, pp. 804-812, 2002.

[2] B. Halliwell, "Oxidative stress, nutrition and health. Experimental strategies for optimization of nutritional antioxidant intake in humans," Free Radical Research, vol. 25, no. 1, pp. 57-74, 1996

[3] S. S. Wallace, "Biological consequences of free radicaldamaged DNA bases," Free Radical Biology and Medicine, vol. 33, no. 1, pp. 1-14, 2002.

[4] E. K. Hudson, B. A. Hogue, N. C. Souza-Pinto et al., "Age-associated change in mitochondrial DNA damage," Free Radical Research, vol. 29, no. 6, pp. 573-579, 1998.

[5] B. Tudek, A. Winczura, J. Janik, A. Siomek, M. Foksinski, and R. Oliński, "Involvement of oxidatively damaged DNA and repair in cancer development and aging," American Journal of Translational Research, vol. 2, no. 3, pp. 254-284, 2010.

[6] A. G. Miller, "Loranthaceae," in Flora of Turkey and the East Aegean Islands, P. H. Davis, Ed., vol. 7, pp. 546-549, University Press, Edinburgh, UK, 1982.

[7] G. Bar-Sela, "White-Berry Mistletoe (Viscum album L.) as complementary treatment in cancer: does it help?" European Journal of Integrative Medicine, vol. 3, no. 2, pp. e55-e62, 2011.

[8] G. Maier and H. H. Fiebig, "Absence of tumor growth stimulation in a panel of 16 human tumor cell lines by mistletoe extracts in vitro," Anti-Cancer Drugs, vol. 13, no. 4, pp. 373-379, 2002.

[9] L. Sabová, M. Pilátová, K. Szilagyi, R. Sabo, and J. Mojžiš, "Cytotoxic effect of mistletoe (Viscum album L.) extract on Jurkat cells and its interaction with doxorubicin," Phytotherapy Research, vol. 24, no. 3, pp. 365-368, 2010.

[10] A. Karagöz, E. Önay, N. Arda, and A. Kuru, "Antiviral potency of mistletoe (Viscum album ssp. album) Extracts against human parainfluenza virus type 2 in Vero cells," Phytotherapy Research, vol. 17, no. 5, pp. 560-562, 2003.

[11] D. D. Orhan, M. Aslan, N. Sendogdu, F. Ergun, and E. Yesilada, "Evaluation of the hypoglycemic effect and antioxidant activity of three Viscum album subspecies (European mistletoe) in streptozotocin-diabetic rats," Journal of Ethnopharmacology, vol. 98, no. 1-2, pp. 95-102, 2005.

[12] E. Önay-Uçar, A. Karagöz, and N. Arda, "Antioxidant activity of Viscum album ssp. album," Fitoterapia, vol. 77, no. 7-8, pp. 556-560, 2006.

[13] A. A. Oluwaseun and O. Ganiyu, "Antioxidant properties of methanolic extracts of mistletoes (Viscum album) from cocoa and cashew trees in Nigeria," African Journal of Biotechnology, vol. 7, no. 17, pp. 3138-3142, 2008.

[14] A. Büssing and M. Schietzel, "Apoptosis-inducing properties of Viscum album L. extracts from different host trees, correlate with their content of toxic mistletoe lectins," Anticancer Research, vol. 19, no. 1, pp. 23-28, 1999.

[15] N. E. Gardin, "Immunological response to mistletoe (Viscum album L.) in cancer patients: a four-case series," Phytotherapy Research, vol. 23, no. 3, pp. 407-411, 2009.

[16] T. Mosmann, "Rapid colorimetric assay for cellular growth and survival: application to proliferation and cytotoxicity assays," Journal of Immunological Methods, vol. 65, no. 1-2, pp. 55-63, 1983.

[17] H. Aebi, "Catalase," in Methods of Enzymatic Analysis, H. U. Bergmeyer, Ed., pp. 673-684, Academic Press, New York, NY, USA, 1974. 
[18] E. Pick and Y. Keisari, "A simple colorimetric method for the measurement of hydrogen peroxide produced by cells in culture," Journal of Immunological Methods, vol. 38, no. 1-2, pp. 161-170, 1980.

[19] A. Negre-Salvayre, N. Augé, C. Duval et al., "Detection of intracellular reactive oxygen species in cultured cells using fluorescent probes," Methods in Enzymology, vol. 352, article 5, pp. 62-71, 2002.

[20] Ö. Erol, N. Arda, and G. Erdem, "Phenols of virgin olive oil protects nuclear DNA against oxidative damage in HeLa cells," Food and Chemical Toxicology, vol. 50, pp. 3475-3479, 2012.

[21] Z. Fan, P. J. Beresford, D. Zhang et al., "Cleaving the oxidative repair protein Ape I enhances cell death mediated by granzyme A," Nature Immunology, vol. 4, no. 2, pp. 145-153, 2003.

[22] S. Ayala-Torres, Y. Chen, T. Svoboda, J. Rosenblatt, and B. Van Houten, "Analysis of gene-specific DNA damage and repair using quantitative polymerase chain reaction," Methods, vol. 22 , no. 2, pp. 135-147, 2000.

[23] F. M. Yakes and B. van Houten, "Mitochondrial DNA damage is more extensive and persists longer than nuclear DNA damage in human cells following oxidative stress," Proceedings of the National Academy of Sciences of the United States of America, vol. 94, no. 2, pp. 514-519, 1997.

[24] D. P. Kalinowski, S. Illenye, and B. van Houten, "Analysis of DNA damage and repair in murine leukemia L1210 cells using a quantitative polymerase chain reaction assay," Nucleic Acids Research, vol. 20, no. 13, pp. 3485-3494, 1992.

[25] R. E. Shackelford, W. K. Kaufmann, and R. S. Paules, "Oxidative stress and cell cycle checkpoint function," Free Radical Biology and Medicine, vol. 28, no. 9, pp. 1387-1404, 2000.

[26] V. Lobo, A. Patil, A. Phatak, and N. Chandra, "Free radicals, antioxidants and functional foods: impact on human health," Pharmacognosy Reviews, vol. 4, no. 8, pp. 118-126, 2010.

[27] Z. Liu, L. Sun, L. Zhu et al., "Hydroxytyrosol protects retinal pigment epithelial cells from acrolein-induced oxidative stress and mitochondrial dysfunction," Journal of Neurochemistry, vol. 103, no. 6, pp. 2690-2700, 2007.

[28] J. Dai and R. J. Mumper, "Plant phenolics: extraction, analysis and their antioxidant and anticancer properties," Molecules, vol. 15, no. 10, pp. 7313-7352, 2010.

[29] L. Nousis, P. T. Doulias, N. Aligiannis et al., "DNA protecting and genotoxic effects of olive oil related components in cells exposed to hydrogen peroxide," Free Radical Research, vol. 39, no. 7, pp. 787-795, 2005.

[30] S. Pavlica and R. Gebhardt, "Protective effects of ellagic and chlorogenic acids against oxidative stress in PC12 cells," Free Radical Research, vol. 39, no. 12, pp. 1377-1390, 2005.

[31] L. E. Bennetts, G. N. De Iuliis, B. Nixon et al., "Impact of estrogenic compounds on DNA integrity in human spermatozoa: evidence for cross-linking and redox cycling activities," Mutation Research, vol. 641, no. 1-2, pp. 1-11, 2008.

[32] Y. H. Wei and H. C. Lee, "Oxidative stress, mitochondrial DNA mutation, and impairment of antioxidant enzymes in aging," Experimental Biology and Medicine, vol. 227, no. 9, pp. 671$682,2002$.

[33] F. Q. Liang and B. F. Godley, "Oxidative stress-induced mitochondrial DNA damage in human retinal pigment epithelial cells: a possible mechanism for RPE aging and age-related macular degeneration," Experimental Eye Research, vol. 76, no. 4, pp. 397-403, 2003.

[34] T. Lindahl, "Instability and decay of the primary structure of DNA," Nature, vol. 362, no. 6422, pp. 709-715, 1993. 


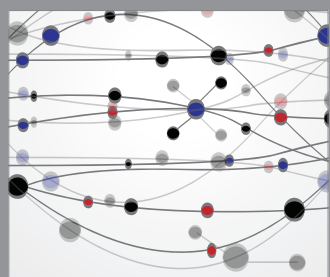

The Scientific World Journal
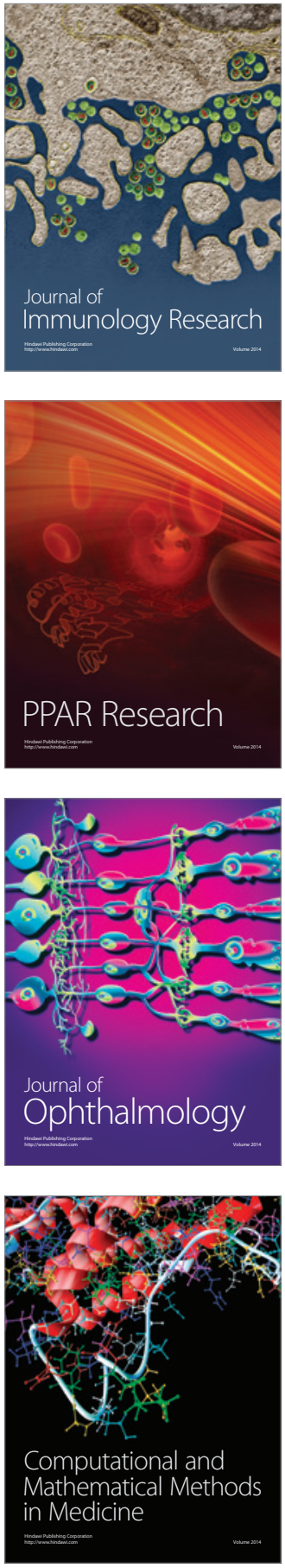

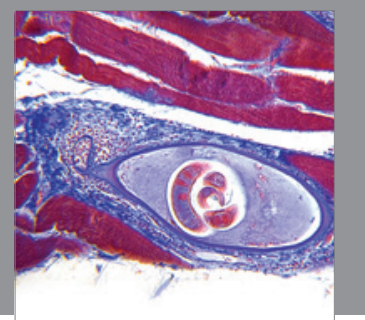

Gastroenterology

Research and Practice
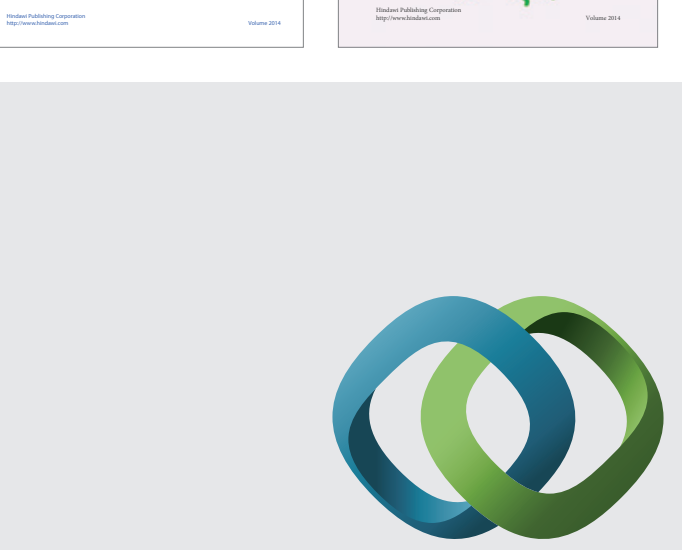

\section{Hindawi}

Submit your manuscripts at

http://www.hindawi.com
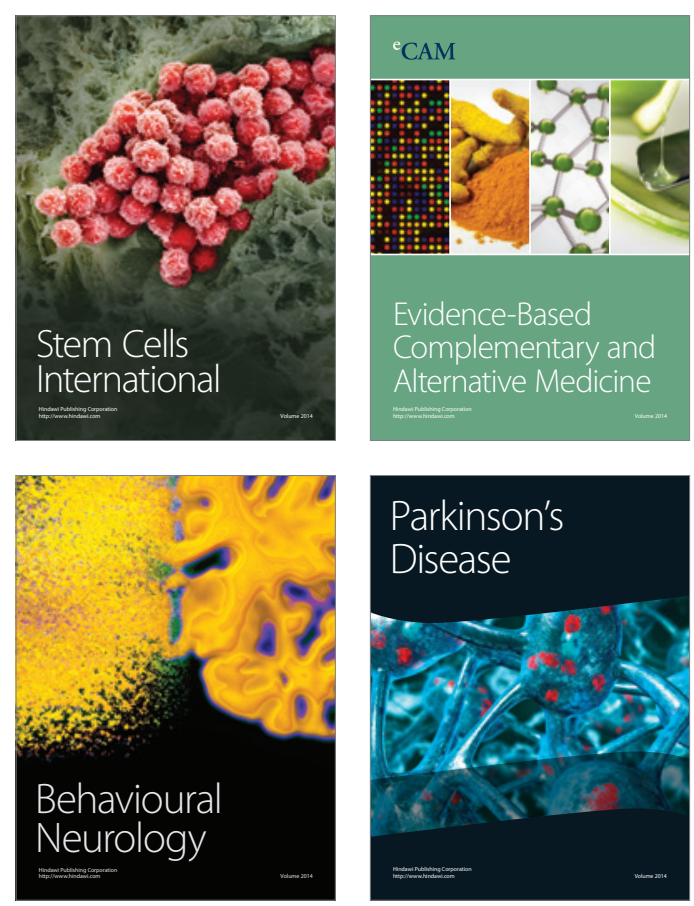

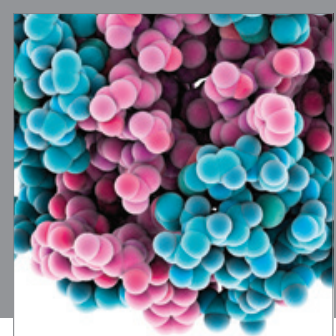

Journal of
Diabetes Research

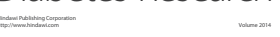

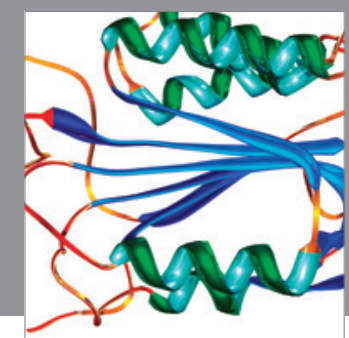

Disease Markers
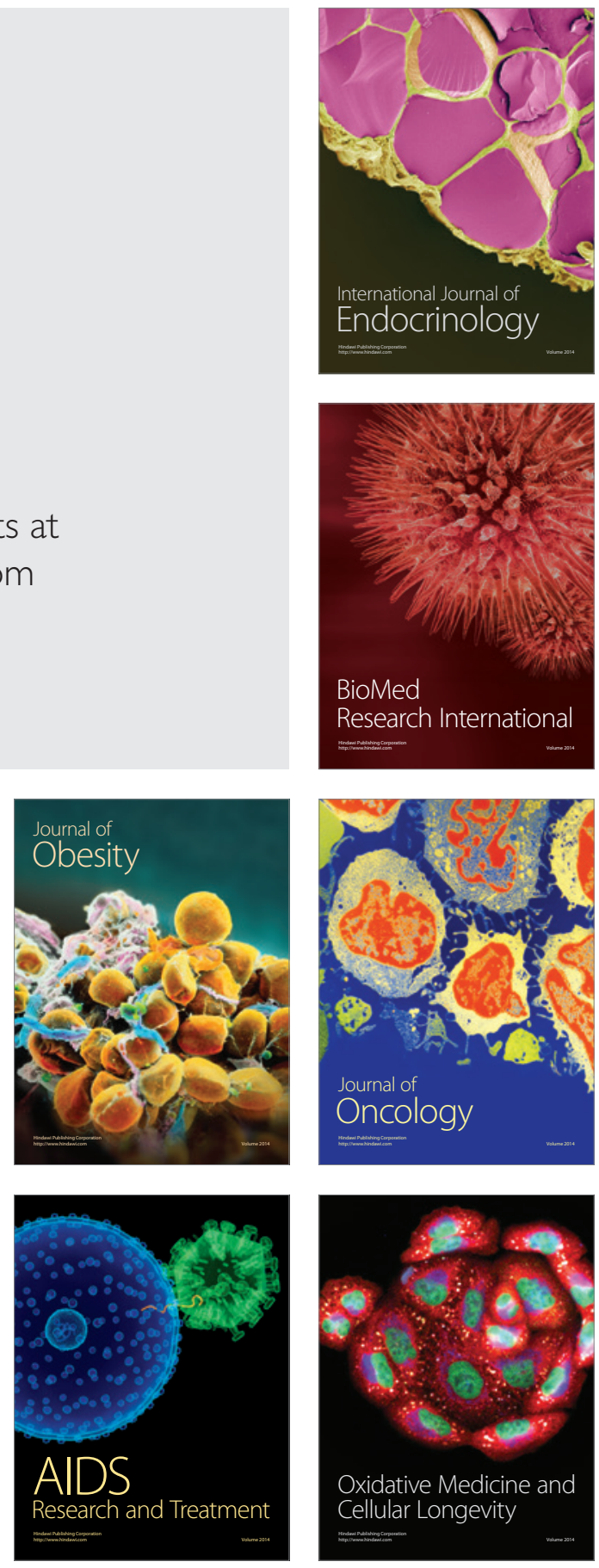